\title{
Communication
}

\section{Superovulation in cattle: practical aspects of gonadotropin treatment and insemination}

\author{
Wilhelm KANITZ $^{\mathrm{a} *}$, Frank BECKER ${ }^{\mathrm{a}}$, Falk SCHNEIDER ${ }^{\mathrm{a}}$, \\ Ellen KANITZ ${ }^{\mathrm{b}}$, Claus LEIDING ${ }^{\mathrm{c}}$, Hans-Peter NOHNER ${ }^{\mathrm{c}}$, \\ Ralf PÖHLAND ${ }^{\mathrm{a}}$ \\ ${ }^{a}$ Department of Reproductive Biology, Research Institute for the Biology of Farm Animals, \\ 18196 Dummerstorf, Germany \\ ${ }^{b}$ Department of Behavioural Physiology, Research Institute for the Biology of Farm Animals, \\ 18196 Dummerstorf, Germany \\ ${ }^{c}$ Besamungsverein Neustadt a.d. Aisch, Neustadt, Germany
}

\begin{abstract}
Embryo transfer (ET) in cattle has been used for the realisation of breeding programmes world-wide for more than 20 years. The efficiency of breeding technology, i.e. the breeding progress and costs, depends to a large extent on the results of superovulatory treatment and artificial insemination (A.I.). The results of this step are characterised by a high degree of variation. Numerous attempts have been undertaken to explain the reason(s) for this. Numerous attempts have also been made to clarify the importance of different factors affecting the results. Undoubtedly, the applied hormones and the scheme of insemination itself are main factors, which influence the number and the portion of transferable embryos. Therefore this paper is focused on the following aspects of superovulatory treatment with FSH: dose-response relations, bioactivity of the glycoprotein, $\mathrm{FSH} / \mathrm{LH}$ ratio, ovulation time and time-oriented insemination, frequency of gonadotropin administration and follicular population at the time of gonadotropin application.
\end{abstract}

cattle / superovulation / FSH / follicles / ovulation / time-oriented insemination

\section{DOSE-RESPONSE RELATIONS}

The ovulation number and the following number of recovered oocytes and embryos show a dose-dependent pattern. This was partly or fully shown for hMG [47], eCG
$[25,46,56]$ and FSH [18, 21, 24, 42, 44, 48, 63]. Kanitz et al. [32] showed for FSH that with increasing doses the number of ovulations increases significantly until a plateau was reached for the parameter. It was not possible to increase ovulation number

* Correspondence and reprints

E-mail:wkanitz@fbn-dummerstorf.de 


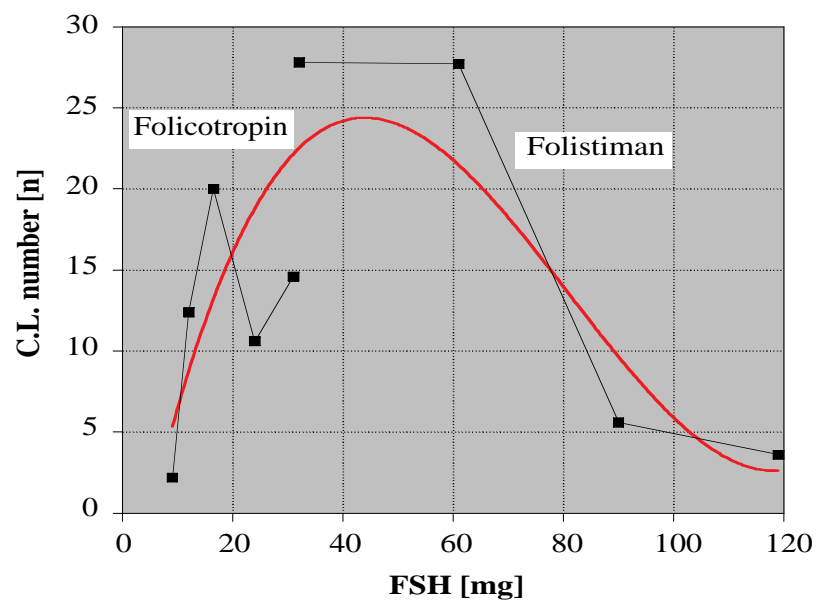

Figure 1. Polynomial regression of the 3rd degree for dose-response relations after FSH application in model studies ( $n=5$ animals per point).

with further increasing FSH doses. On the contrary, very high FSH doses were followed by a depression in ovulation number (Fig. 1) as shown for eCG [56]. The mechanisms responsible for the decrease in ovulation number are not well understood. Saumande and Chupin [57] speculate that the depression of ovulations is more dependent on the type of gonadotropin than on the FSH/LH ratio. In our experiments we found that high FSH doses can disturb the ovulation process at two levels, at the level of the pituitary and at the ovarian level. On the one hand, the portion of animals with an LH surge decreased. On the other hand, the number of follicles, which ovulated after an LH surge decreased (Tab. I). Increased progesterone concentrations during oestrus are involved, at least in the depression of an LH surge by inhibiting the development of the positive estrogen feedback. Another reason for a reduced ovulation number may consist in a downregulation of follicular FSH receptors by high doses of the homologous ligand. The results of a field trial with a uniform application and insemination schedule allow the conclusion that each FSH product has an optimal dose range (Fig. 2).

\section{BIOACTIVITY OF FSH PRODUCTS}

Different pharmaceutical products with gonadotropins as their active substance and moreover batches of one product can differ in their bioactivity and/or immunoactivity $[4,6,19,43]$. The reasons consist in the differences in the specific protein content and in the different bioactivities of the gonadotropin which depend on the degree of glycosilation of the molecules and on the occurrence of the isoforms $[9,15,45,62$, $68,80]$. Although such differences have been well known for many years, no data have been available regarding their consequences on superovulation results. We examined the bioactivity of four different batches of one commercially available FSH product with an in vivo bioassay [4]. The relative bioactivity was in the range of $78.9 \%$ to $127.8 \%$. The four batches were used for superovulation. Dairy cows $(n=525)$ from day 60 to 90 after calving received eight injections of FSH (total amount $24 \mathrm{mg}$ ) in decreasing doses from day 10 to 12 of the oestrous cycle. $\mathrm{PGF}_{2 \alpha}$ was given 48 and $60 \mathrm{~h}$ after the first FSH injection. Thereafter 
Table I. Estradiol and progesterone concentrations, number of animals with LH surge and ovulation number in dependence on FSH dose.

\begin{tabular}{lccccc}
\hline $\begin{array}{c}\text { FSH } \\
(\mathrm{mg})\end{array}$ & $\begin{array}{c}\text { Animals } \\
(n)\end{array}$ & $\begin{array}{c}\text { E2-Maximum } \\
\text { during estrus } \\
\left(\mathrm{pg} \cdot \mathrm{mL}^{-1}\right) \\
\mathrm{x} \pm \mathrm{s}\end{array}$ & $\begin{array}{c}\text { P4-Concentration } \\
\text { during estrus } \\
\left(\mathrm{ng} \cdot \mathrm{mL}^{-1}\right) \\
\mathrm{x} \pm \mathrm{s}\end{array}$ & $\begin{array}{c}\text { Animals } \\
\text { with LH surge } \\
(n)\end{array}$ & $\begin{array}{c}\text { Corpora lutea } \\
(n)\end{array}$ \\
\hline 32 & 5 & $74.6^{\mathrm{a}} \pm 29.7$ & $1.2^{\mathrm{a}} \pm 0.3$ & 5 & $\mathrm{x} \pm \mathrm{s}$ \\
61 & 5 & $67.2^{\mathrm{a}} \pm 15.4$ & $1.2^{\mathrm{a}} \pm 0.4$ & 5 & $27.8^{\mathrm{a}} \pm 16.4$ \\
90 & 5 & $64.0^{\mathrm{a}} \pm 13.8$ & $1.6^{\mathrm{b}} \pm 0.7$ & 3 & $5.6^{\mathrm{b}} \pm 5.1$ \\
119 & 5 & $44.8^{\mathrm{b}} \pm 14.9$ & $1.7^{\mathrm{b}} \pm 0.3$ & 2 & $3.6^{\mathrm{b}} \pm 7.2$ \\
\hline
\end{tabular}

a:b $p<0.05$.

Figure 2. Dose-response relations after $\mathrm{FSH}$ application in a clinical study $(n=584$ cows $)$.

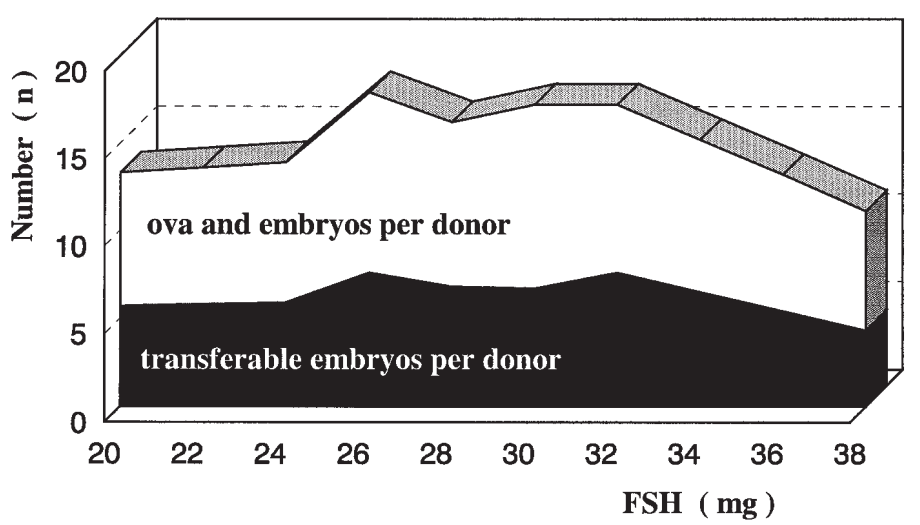

all cattle were time-oriented inseminated. FSH batches were used independent of the relative bioactivity. The results of superovulatory treatment were significantly influenced by the bioactivities of the batches (Tab. II). The mean fertilisation rates did not differ significantly between the groups.

\section{FSH/LH RATIO}

FSH preparations produced from the pituitaries also contain other biological active substances like LH besides FSH. The amounts of FSH and LH and their activities can be different for different batches of one product and for different products [17, $43,55]$. Determination of the amounts or activities is done with assays which, recognise either the structure or the function of the hormones [49]. The results of determination of FSH and LH contents in different FSH products or the activities of the hormones cannot be compared between products because different assays and different standard hormones are often used. The more important question is the possible biological effect of the so called FSH/LH ratio. Donaldson et al. [19], Beckers [3], Chupin et al. [11], Gonzales et al. [24], Tribulo et al. [67], and Yamamoto et al. [79] showed that FSH products with reduced LH content give higher ovulation number, fertilisation rate and embryo quality. It is speculated [29] that "high" LH activities cause luteinisation of follicles, receptor down regulation and premature ovulations. "Low" LH activities should cause deviation in oocyte maturation, 
Table II. Relative bioactivity in four batches of one FSH product and results of superovulation and embryo recovery after application of $24 \mathrm{mg}$ FSH per donor independent of bioactivity ( $n=525$ cows).

\begin{tabular}{cccc}
\hline Batch & $\begin{array}{c}\text { Relative bioactivity } \\
(\%)\end{array}$ & $\begin{array}{c}\text { Recovered eggs } \\
\text { and embryos per donor } \\
(n) \\
\mathrm{x} \pm \mathrm{s}\end{array}$ & $\begin{array}{c}\text { Transferable embryos } \\
\text { per donor } \\
(n) \\
\mathrm{x} \pm \mathrm{s}\end{array}$ \\
\hline 1 & 127.8 & $10.3^{\mathrm{a}} \pm 7.2$ & $7.4^{\mathrm{a}} \pm 5.3$ \\
2 & 106.0 & $10.2 \pm 7.3$ & $6.8 \pm 5.5$ \\
3 & 89.0 & $8.9^{\mathrm{c}} \pm 5.7$ & $6.4 \pm 4.6$ \\
4 & 78.9 & $8.1^{\mathrm{b}} \pm 6.4$ & $6.1^{\mathrm{c}} \pm 5.5$ \\
\hline
\end{tabular}

a:b $p<0.01$, a:c $p<0.05$.

fertilisation and early embryonic development [29]. Moreover, the "right" FSH/LH ratio should be able to reduce the variability of the superovulatory response. This was the background for requesting FSH products with reduced LH content or highly purified FSH. But the above cited results have not been uncontradicted $[52,71]$. Because the effects of FSH/LH ratios are usually assessed in terms of the number or quality of recovered oocytes or embryos after superovulatory treatment we determined the effects of gonadotropin preparations with different FSH/LH ratios on follicular growth, portion of atretic follicles and $\mathrm{FSH}$ and $\mathrm{LH}$ binding of granulosa cells.

Crossbred heifers $(n=78)$ were randomly divided into 4 groups. Animals received purified porcine pituitary hormone preparations (Ovaset ${ }^{\circledR}$, Sanofi) in a total amount (according NIH-P1 standard) of $0.29 \mathrm{mg}$ FSH (FSH group), $0.29 \mathrm{mg} \mathrm{FSH}$ and $0.19 \mathrm{mg} \mathrm{LH}$ (FSH/LH group) or $0.19 \mathrm{mg} \mathrm{LH}$ (LH group) in a treatment of 6 injections on 3 consecutive days starting on day 10 of the oestrous cycle. Untreated animals (buffered saline, 6 injections) with the same stage of the cycle were used as the control. The ovaries were recovered $76 \mathrm{~h}$ after the first injection. Follicles of all ovaries were counted and classified according to size. Altogether 1668 follicles from 49 animals were classified as atretic or nonatretic by a macroscopic method [40]. Granulosa cells from individual follicles ( $>2 \mathrm{~mm}$ diameter) were analysed by flow cytometry for the detection of FSH and LH binding using an indirect quantitative immunofluorescence technique [FITC-labelled anti-hormone-antibodies (UCB) were used for staining after incubation of the cells with ligands]. Statistical analysis were done by EPICS ELITE (Coulter) or by means of the Statistical Analysis Package SAS ${ }^{\circledR}$ [33]. The results are summarised below.

FSH and FSH/LH treatments significantly increased the number of medium and large follicles. LH treatment alone was not able to induce follicular growth (Tab. III). FSH binding capacity on granulosa cells was significantly stimulated by the homologous ligand (Fig. 3) whereas the LH binding capacity was not significantly different between the groups. Finally, the portion of nonatretic follicles was significantly influenced by hormone treatment (Tab. IV). LH was not necessary for superovulatory treatment, but it was also tolerated to a certain amount without negative effects on superovulatory response (Tab. IV).

In the light of the discussion about the effects of LH in FSH products, the results of superovulation after application of recombinant FSH (rFSH) are interesting. Although the first report of the results [72] was very encouraging, the following data [73] showed, that it was neither possible to increase the number of transferable embryos nor possible to decrease the variance of the results through the application of $\mathrm{rFSH}$. 
More recently Takagi et al. [66] investigated whether recombinant human FSH (rhFSH) without contaminating LH can exert a normal superovulation response in cows. One group of heifers $(n=9)$ was stimulated with rhFSH and another group $(n=9)$ was treated with equine chorionic gonadotrophin (eCG). Daily transrectal ultrasonography showed

Table III. Follicular populations after treatment of heifers with FSH, FSH/LH, LH or NaCl.

\begin{tabular}{|c|c|c|c|c|c|c|}
\hline & & & $\begin{array}{c}\text { FSH } \\
0.29 \mathrm{mg}\end{array}$ & $\begin{array}{c}\text { FSH/LH } \\
0.29 / 0.19 \mathrm{mg}\end{array}$ & $\begin{array}{c}\mathrm{LH} \\
0.19 \mathrm{mg}\end{array}$ & $\begin{array}{c}\text { Control } \\
\mathrm{NaCl}\end{array}$ \\
\hline Animals & $(n)$ & & 21 & 20 & 18 & 19 \\
\hline Follicles $1-3,9 \mathrm{~mm}$ & $(n)$ & $\mathrm{x} \pm \mathrm{s}$ & $14.3^{\mathrm{a}} \pm 10.2$ & $11.6^{\mathrm{a}} \pm 10.4$ & $23.5^{\mathrm{b}} \pm 15.0$ & $28.0^{\mathrm{b}} \pm 17.2$ \\
\hline Follicles $4-8 \mathrm{~mm}$ & $(n)$ & $\mathrm{x} \pm \mathrm{s}$ & $9.1^{\mathrm{c}} \pm 5.2$ & $8.7^{\mathrm{c}} \pm 5.3$ & $5.0^{\mathrm{d}} \pm 2.9$ & $4.7^{\mathrm{d}} \pm 3.4$ \\
\hline Follicles $>8 \mathrm{~mm}$ & $(n)$ & $x \pm s$ & $15.6^{\mathrm{e}} \pm 12.1$ & $12.7^{\mathrm{e}} \pm 9.7$ & $1.9^{\mathrm{f}} \pm 1.1$ & $1.9^{\mathrm{f}} \pm 1.4$ \\
\hline Total & $(n)$ & $\mathrm{x} \pm \mathrm{s}$ & $39.0 \pm 17.3$ & $33.1 \pm 16.7$ & $31.0 \pm 15.8$ & $31.0 \pm 17.1$ \\
\hline Min. $-\max$ & (n) & & $17-73$ & $6-71$ & $12-67$ & $11-79$ \\
\hline
\end{tabular}

a:b, c:d, e:f $p<0.05$.

Figure 3. FSH binding capacity on granulosa cells after treatment of cattle with FSH, FSH/LH, LH or saline.

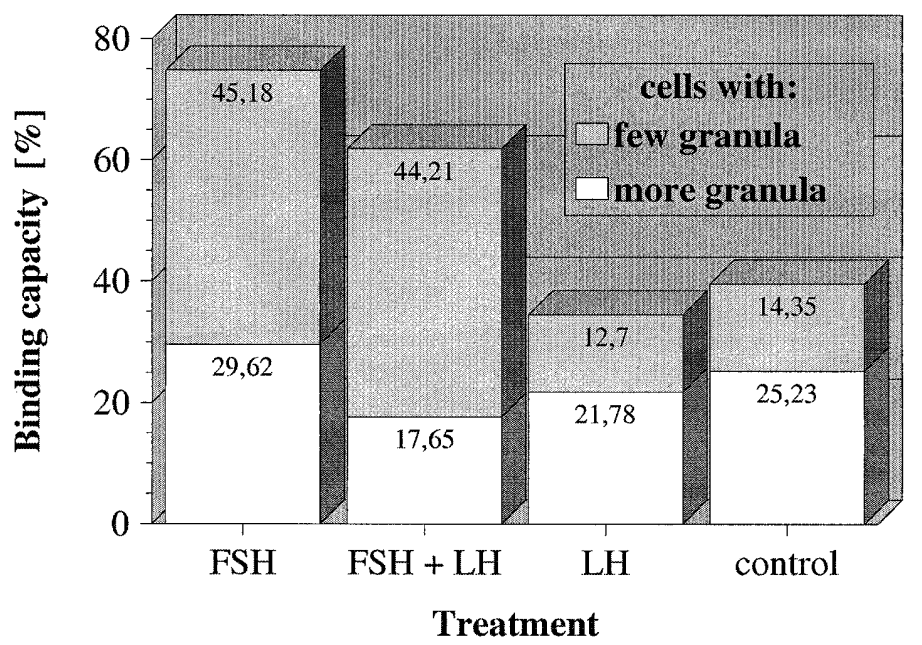

Table IV. Portion of intact follicles and results of superovulation and embryo recovery in dependence on treatment with FSH, FSH/LH or LH.

\begin{tabular}{lcccccc}
\hline Treatment & $\begin{array}{c}\text { Ovaries } \\
(n)\end{array}$ & $\begin{array}{c}\text { Portion of intact } \\
\text { follicles } \\
(\%)\end{array}$ & $\begin{array}{c}\text { Animals } \\
(n)\end{array}$ & $(n)$ & $\begin{array}{c}\text { Corpora lutea } \\
\text { Transferable } \\
\text { embryos } \\
(n)\end{array}$ & $(\%)$ \\
\hline FSH & 4 & $46^{\mathrm{a}}$ & 5 & $18.0^{\mathrm{d}} \pm 1.2$ & $6.6^{\mathrm{f}} \pm 4.9$ & 78 \\
FSH/LH & 4 & $37^{\mathrm{a}}$ & 5 & $13.2^{\mathrm{d}} \pm 5.2$ & $8.8^{\mathrm{f}} \pm 4.0$ & 98 \\
LH & 4 & $6^{\mathrm{b}}$ & 5 & $1.2^{\mathrm{e}} \pm 0.4$ & $0.2^{\mathrm{g}} \pm 0.4$ & \\
Control & 4 & $18^{\mathrm{c}}$ & 5 & & & \\
\hline
\end{tabular}

a:b $p<0.01$, b:c, d:e., f:g $p<0.05$. 
that eCG- and rhFSH-stimulated heifers had the same follicular growth characteristics and equal numbers of follicles $>8 \mathrm{~mm}$ in diameter after 3 days of stimulation. But there were considerable differences in steroid production between the groups. rhFSH-treated heifers had lower oestradiol concentrations during the first days of stimulation and lower progesterone concentrations in the period after the LH surge than did the eCG-stimulated animals. Moreover rhFSH-treated heifers had fewer LH pulses than did the eCG-treated heifers and the LH surge occurred later. Multiple ovulations occurred in only three of six rhFSH-treated heifers, but in all four eCG-treated heifers with an LH surge. At $24 \mathrm{~h}$ after the $\mathrm{LH}$ surge, the percentage of metaphase II stage oocytes with cortical granules distributed close to the oolemma was significantly lower in the rhFSH group $(7.3 \%)$ than in the eCG group (55.9\%). The authors concluded, that the final follicular maturation was impaired in heifers treated with $\mathrm{rhFSH}$, which might be due to the combination of a lack of LH activity in the gonadotrophin preparation and the severe suppression of LH pulsatility. But it has to be considered, that the dose of rhFSH for superovulation of cattle was based on reported doses of human menopausal gonadotropin and rhFSH for human treatment. Moreover Gosselin et al. [26] found that there was no significant correlation between estradiol or progesterone and LH pulse frequency, amplitude and mean concentrations at any time in the control or superovulated animals. Their study demonstrates that superovulation treatment in the cow causes a rapid decrease in the pulsatile release of $\mathrm{LH}$ and suggests that this effect is not mediated through the negative feedback actions of estradiol and progesterone.

\section{OVULATION TIME AND TIME-ORIENTED INSEMINATION}

To determine the ovulation period (i.e. first ovulation, last ovulation) different direct and indirect methods can be used. The most uncertain direct method is rectal palpation. It only allows to recognise if the animal is in the process of ovulation. With some experience, the number of ovulations can be roughly estimated. The method of endoscopy is much better and allows the sure determination of the first ovulation. Unfortunately it is not possible to detect all ovulations, especially in the cases of high numbers of ovulations when blood is present on the surface of the ovaries during the ovulation period. The use of ultrasound is the most less invasive method. But the first and moreover the last ovulation are not easily detectable. LH determination can be used as an indirect method because the time interval between the LH surge and start of ovulation is relatively constant and in most of the papers shows no large variation. When FSH was used for stimulation of follicular growth, the mean time intervals from induction of luteolysis to LH surge ranged from 44 to $48 \mathrm{~h}$. The standard deviation for the parameter was between 2 and $12 \mathrm{~h}$ [27, 41, 75, 76]. We also investigated the time interval from the induction of luteolysis to the LH surge.

Therefore, altogether 39 heifers and cows were treated 8 times with FSH for 4 days starting between day 10 to 12 of the oestrous cycle. $\mathrm{PGF}_{2 \alpha}$ was given 48 and $60 \mathrm{~h}$ after the first FSH injection. All animals received jugular catheters. Blood samples were drawn via catheters every second hour for $\mathrm{LH}$ determination. The mean time interval form $\mathrm{PGF}_{2 \alpha}$ to $\mathrm{LH}$ surge was $46.5 \pm 4.4 \mathrm{~h}$. It was independent of the factor 'heifer' or 'cow'. Based on a 6 hourly endoscopic observation of the ovaries of these animals, we detected the start of ovulations 62 to $68 \mathrm{~h}$ after induction of luteolysis. This was in agreement with observations made by others $[1,50]$. The authors observed the start of ovulations by means of ultrasound diagnosis 68 to $69 \mathrm{~h}$ after the induction of luteolysis. The standard deviation for the parameter was very small. In our investigations and in those of others [14, 41] it took 24-30 h from the LH surge until the start of ovulations. 
The time interval from the first to the last ovulation varied from 1.2 to $12 \mathrm{~h}[1,41$, 50, 77].

Based on these data, we developed the following scheme for a time-oriented insemination in heifers and cows (Fig. 4). The time necessary for capacitation of sperm cells from bulls (approximately $6 \mathrm{~h}$ ) is considered in the scheme. We investigated the fertilisation rate after superovulatory treatment with FSH and time-oriented insemination. Altogether 180 cows were flushed one time after a single superovulatory treatment and 43 cows were flushed 145 times after a repeated superovulatory treatment. All cows were inseminated according to data in Figure 4. For each insemination, one straw with 20 million sperm cells was used.
After thawing in a water bath $\left(38^{\circ} \mathrm{C}, 15 \mathrm{~s}\right)$, insemination was done in the uterus. Flushing of the uterus was performed on day 7 . Using the time-oriented insemination after superovulation of the cows with $\mathrm{FSH}$, fertilisation rates were above $85 \%$ after the first or repeated superovulatory treatment (Tab. V). The fertilisation rates obtained with time-oriented insemination were higher than those between 60 and $70 \%$ normally reached under routine conditions [52, 69]. They are comparable with recent results from Dalton et al. [13]. These authors reached an $81 \%$ fertilisation rate under experimental conditions in a relatively small group of animals ( $n=10$ cows) with one insemination $24 \mathrm{~h}$ after standing heat. In contrast to our experiments, 50 million sperm cells were used for one insemination.
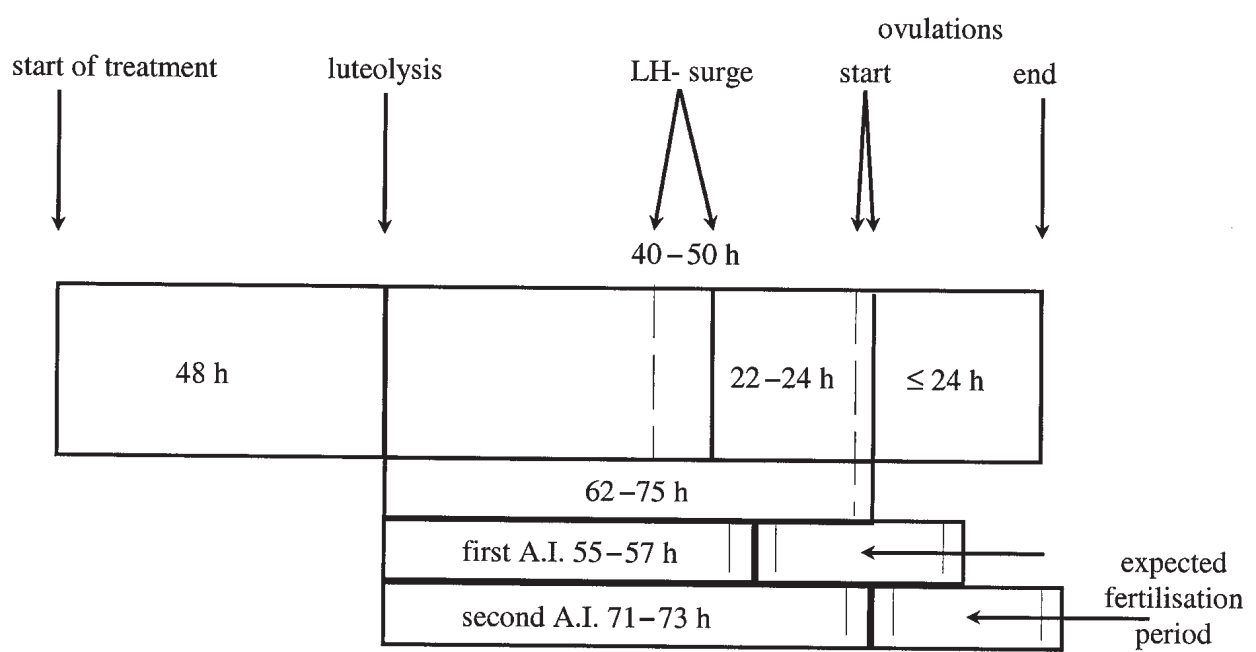

Figure 4. Scheme for time-oriented insemination in superovulated cattle.

Table V. Results of time-oriented insemination in superovulated cows stimulated once or repeatedly.

\begin{tabular}{lcccc}
\hline $\begin{array}{l}\text { Donor } \\
\text { number } \\
(n)\end{array}$ & Recoveries & $\begin{array}{c}\text { Ova and embryos } \\
\text { per recovery } \\
(n)\end{array}$ & $\begin{array}{c}\text { Embryos } \\
\text { per recovery } \\
(n)\end{array}$ & $\begin{array}{c}\text { Fertilisation } \\
\text { rate } \\
(\%)\end{array}$ \\
\hline 180 & $(n)$ & 9.0 & 7.7 & 85.6 \\
43 & 180 & 9.8 & 8.4 & 86.2 \\
\hline
\end{tabular}




\section{FREQUENCY OF FSH APPLICATION}

In most cases $\mathrm{FSH}$ is given two times per day for four days [16, 23, 36]. But there have been attempts to decrease the number of injections. Purwantara et al. [51] concluded from their experiments, that treatment with Folltropin once daily for 3 days gives a folliculogenic and superovulatory response similar to a treatment regimen where it is given twice daily for 4 days. Other data $[36,58,61,65,78]$ suggest that the multiple intramuscular injections of FSH can be replaced by a single injection, given subcutaneously. But data from Callejas [10] show that a single injection of FSH-P was not sufficient enough to give the same results reached with eight injections of the same product. Superovulation can also be induced by a single injection of hMG [64]. Kelly et al. [36] investigated the superovulatory response, estradiol concentrations and follicular populations in regard to single or multiple injections of FSH using two different FSH products. The authors found that estradiol concentrations can be significantly influenced by the frequency of the FSH application and FSH product.

In our own experiments FSH application (Folltropin ${ }^{\circledR}$, Vetrepharm, Canada) twice daily for 4 days was compared with an application once a day. Superovulatory treatment was started in Simmental cows between day 8 to 13 of the oestrous cycle. Control animals (group 1) received 8 injections of FSH (total dose: $400 \mathrm{mg}$ ). The animals in groups 2 and 3 received only one injection per day for four days. The total dose for FSH was $360 \mathrm{mg}$ in group 2 and $260 \mathrm{mg}$ in group 3. $\mathrm{PGF}_{2 \alpha}$ was given 72 and $82 \mathrm{~h}$ after the first FSH injection. Insemination was done in the same way in all animals. Our results indicate that $\mathrm{FSH}$ application once a day can be as efficient as a twice daily injection (Tab. VI).

\section{FOLLICULAR POPULATION AT THE TIME OF TREATMENT}

Response to superovulatory treatment is characterised by a high degree of variation. A review about various factors, which have been reported to influence the response after treatment, is given by Kafi and McGowan [31]. Several authors $[28,30,48,70]$ reported, that the presence of a dominant follicle on the day of initiation of superstimulation decreases the superovulatory response. The ablation of the largest/dominant follicle prior to superovulatory treatment can increase superovulatory response [7, 37, 38, 59], however under field conditions the results could not be repeated [39]. The ablation of the two largest follicles was as efficient as the ablation of all follicles $>5 \mathrm{~mm}$ in diameter [2]. In contrast to this, Bergfelt et al. [5] and Diaz et al. [16] did not find a positive effect of follicle ablation on the superovulatory

Table VI. Results of embryo recovery and evaluation of embryos in dependence on frequency and dose of FSH treatment in Simmental cows.

\begin{tabular}{llcrr}
\hline & & Group 1 (control) & Group 2 & Group 3 \\
\hline FSH dose & $(\mathrm{mg})$ & 400 & 360 & 260 \\
Number of injections & $(n)$ & 8 & 4 & 4 \\
Animals & $(n)$ & 11 & 24 & 31 \\
Ova and embryos per donor & $(n) \mathrm{x}$ & 16.9 & 20.5 & 16.0 \\
Transferable embryos per donor & $(n) \mathrm{x}$ & 10.9 & 9.5 & 11.1 \\
Fertilisation rate & $(\%) \mathrm{x}$ & 76.3 & 65.6 & 79.4 \\
Portion of transferable embryos & $(\%) \mathrm{x}$ & 64.5 & 46.5 & 67.4 \\
\hline
\end{tabular}


response. From these results it was concluded that exogenous FSH treatment appears to override any systemic inhibitory effect that a persistent dominant follicle may be exerting on the pituitary and possibly the ovaries. The opposing results from the different studies can be partly explained by the different time intervals between follicle ablation and superstimulation, by the different time points for ablation (growing phase, static phase or decline phase of the dominant follicle) and by the different criteria for the evaluation of the results.

Several authors $[8,54]$ found that a high number of potential recruitable follicles is associated with a better superovulatory response. Kawamata [35] determined the relationships between the number of small follicles prior to superovulatory treatment and the superovulatory response. A total of 55 superovulations were induced in Holstein cows. The ovaries were examined ultrasonographically once $0-1.5$ days before the initiation of the superovulatory treatment. The number of small follicles 3-6 mm in diameter on both ovaries before the superovulatory treatment was found to be significantly correlated with the numbers of corpora lutea after superovulation $(r=0.440$, $P<0.001)$, total recovered ova $(r=0.503$, $P<0.001)$ and transferable recovered embryos $(r=0.482, P<0.001)$. More recently, Cushmann et al. [12] found that the number of CL is correlated positively with the total number of primordial, tertiary, and medium surface follicles. The number of CL is related to the number of tertiary follicles in a positive linear manner and the number of medium follicles in a positive quadratic manner. In contrast to this, Singh et al. [60] did not find any correlation between the number of follicles observed at the start of the FSH treatment and the number of corpora lutea. Also Fernandez et al. [22] found no significant correlation between the follicular population at the beginning of the treatment and the number of ovulations and embryo yield. Drawing a conclusion from the above-cited results and from the knowledge of follicular dynamics in cattle [14, 20, 34, 53, 74], it can be expected that the ovulation number after superovulatory treatment depends on the number of follicles, which respond to treatment with proliferation, differentiation and ovulation in a period of 120 hours. The quantity and quality of follicles in this pool (Fig. 5) is the main reason for the variability of the superovulatory response. Different results in the literature can be caused by methods for counting and classifying the follicles (i.e. resolution limit of ultrasound).

\section{CONCLUSIONS FOR PRACTISE}

1. To maximise the number of transferable embryos, the applied FSH dose has to be in a product specific optimal range. Comparisons between different FSH products according to this range are not useful because different standards and different assays for estimation of the FSH content or bioactivity of the product are used.

2. A reduced bioactivity of FSH should be considered as one possible reason for insufficient results of the superovulatory treatment. Other factors have to be excluded first.

3. LH contaminations in FSH products are not necessary for successful superovulatory treatments, but contaminations are undoubtedly tolerated to a certain amount without negative effects on the results.

4. Recombinant FSH has no advantage in regard to the mean number of transferable embryos and variance of superovulatory results in comparison to purified FSH from the pituitary. Other factors like BSE or other transmissible diseases are not considered in this conclusion.

5. The knowledge about the ovulation period in superovulated cattle allows successful time-oriented insemination in heifers and cows. Two inseminations are sufficient for high fertilisation rates. It has to be 

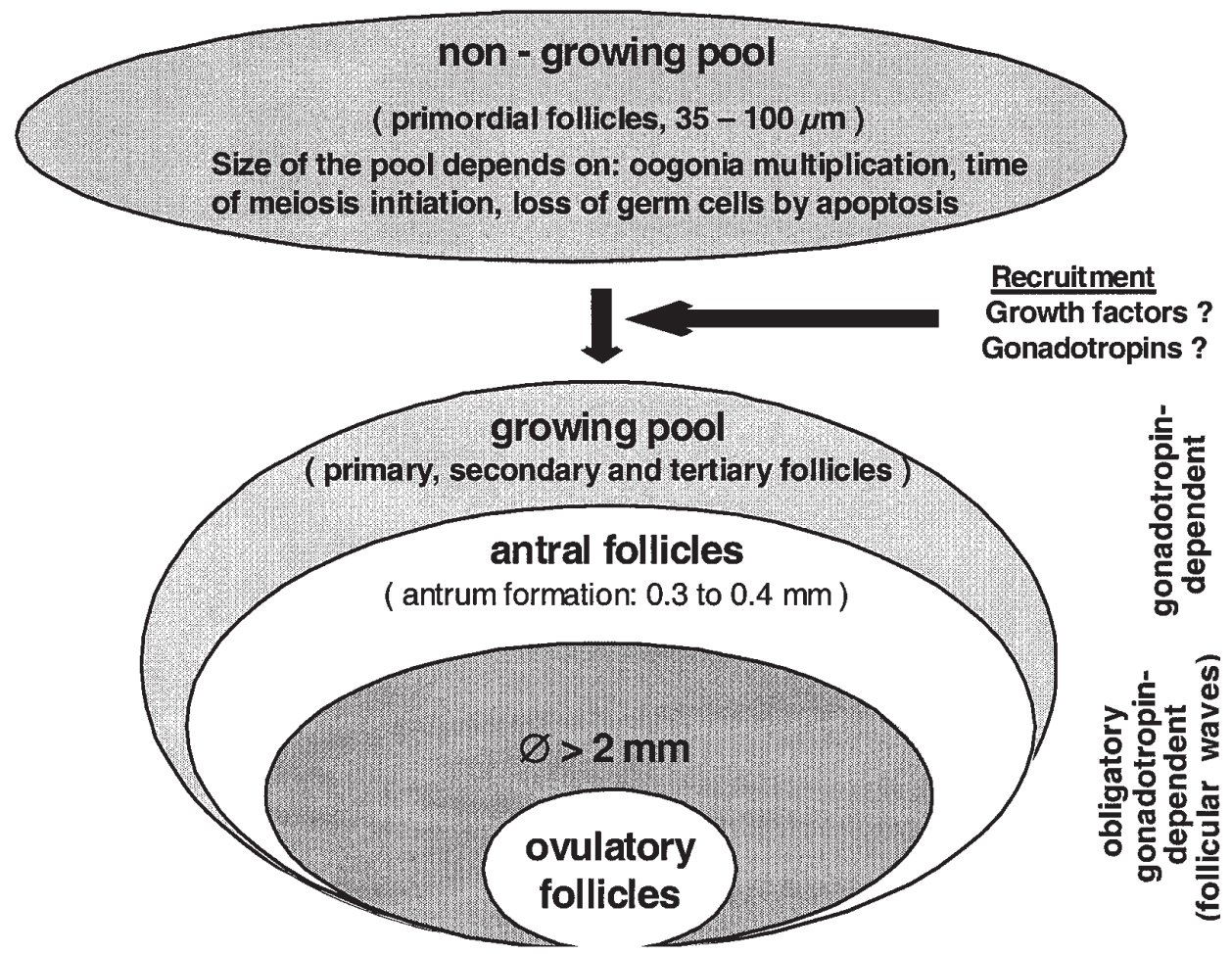

Figure 5. Follicular population in cattle.

considered, that the recommended time for time-oriented A.I. in Figure 4 is valid, when luteolysis is induced $48 \mathrm{~h}$ after the start of gonadotropin treatment.

6. Ablation of the dominant follicle prior to superovulatory treatment can increase the number of transferable embryos. But this treatment cannot reduce the variability after superstimulation, because the main reason for the variation of ovulation number consists in the number of follicles which respond to gonadotropins with proliferation, differentiation and ovulation in a period of $120 \mathrm{~h}$.

7. FSH application once a day can be as efficient as a twice daily application. The application regime has to be tested for each product.

\section{REFERENCES}

[1] Adams G.P., Control of ovarian follicular wave dynamics in cattle: implications for synchronization and superstimulation, Theriogenology 41 (1994) 19-24.

[2] Baracaldo M.I., Martinez M.F., Adams G.P., Mapletoft R.J., Superovulatory response following transvaginal follicle ablation in cattle, Theriogenology 53 (2000) 1239-1250.

[3] Beckers J.F., Isolation and use of porcine FSH to improve the quality of superovulation in cattle, Theriogenology 27 (1987) 213.

[4] Bergfeld J., Guiard V., Uhlig H., Zur Bedeutung, Herstellung und Wertbestimmung eines internationalen PMSG-Substandards, Mh. Vet. Med. 37 (1982) 504-507.

[5] Bergfelt D.R., Bo G.A., Mapletoft R.J., Adams G.P., Superovulatory response following ablation-induced follicular wave emergence at random stages of the oestrous cycle in cattle, Anim. Reprod. Sci. 49 (1997) 1-12. 
[6] Braileanu G.T., Albanese C., Card C., Chedrese P.J., FSH bioactivity in commercial preparations of gonadotropins, Theriogenology 49 (1998) 1031-1037.

[7] Brogliatti G.M., Salamone D.F., Adams G.P., Ovarian follicular wave synchronization an superstimulation in prepubertal calves, Theriogenology 47 (1997) 1253-1264.

[8] Bungartz L., Niemann H., Assessment of the presence of a dominant follicle and selection of dairy cows suitable for superovulation by a single ultrasound examination, J. Reprod. Fertil. 101 (1994) 583-591.

[9] Burgon P.G., Robertson D.M., Stanton P.G., Hearn M.T.W., Immunological activities of highly purified isoforms of human FSH correlate with in vitro bioactivities, Endocrinology 139 (1993) 511-518.

[10] Callejas S.S., Alberio R.H., Cabodevila J.A., Dulout F., Aller J.F., Teruel M.T., Ovarian stimulation with FSH-P in multiple or single dose in Polyvinylpirrolidone or the combination of a reduced dose FSH-P and ECG, Theriogenology 57 (2002) 763 .

[11] Chupin D., Cognie Y., Combarnous Y., Procureur R., Saumande J., Effect of purified $\mathrm{LH}$ and FSH on ovulation in the cow and ewe, in: Roche J.F., O'Callaghan D. (Ed.), Follicular Growth and Ovulation Rate in Farm Animals, Martinus Nijhoff, The Hague, 1987, pp. 66-72.

[12] Cushman R.A., DeSouza J.C., Hedgpeth V.S., Britt J.H., Superovulatory response of one ovary is related to the micro- and macroscopic population of follicles in the contralateral ovary of the Cow, Biol. Reprod. 60 (1999) 349-354.

[13] Dalton J.C., Nadir S., Bame J.H., Noftsinger M., Saacke R.G., The effect of time of artificial insemination on fertilization status and embryo quality in superovulated cows, J. Anim. Sci. 78 (2000) 2081-2085.

[14] Dieleman S.J., Bevers M.M., Folliculogenesis and oocyte maturation in superovulated cattle, Mol. Reprod. Dev. 36 (1993) 271-273.

[15] Dirnhofer S., Lechner O., Madersbacher S., Klieber R., deLeeuw R., Wick G., Berger P., Free subunit of human chorionic gonadotrophin: molecular basis of immunologically and biologically active domains, Endocrinology 140 (1994) 145-154.

[16] Diaz T., Pancarci S.M., Drost M., Schmitt E.J., Ambrose J.D., Fredriksson W.E., Thatcher W.W., Effects of the persistent dominant follicle on the ability of follicle stimulating hormone to induce follicle development and ovulatory responses, J. Dairy Sci. 84 (2001) 88-99.

[17] Donaldson L.E., FSH-P batch variation, Theriogenology 33 (1990) 215

[18] Donaldson L.E., Ward D.N., Superovulation in cattle: Dose-Response to FSH-W with and without LH contamination, Theriogenology 23 (1985) 189.
[19] Donaldson L.E., Ward D.N., Glenn S.G., Use of porcine follicle stimulating hormone after chromatographic purification in superovulation of cattle, Theriogenology 25 (1986) 747-757.

[20] Driancourt M.A., Regulation of ovarian follicular dynamics in farm animals. Implications for manipulation of reproduction, Theriogenology 55 (2001) 1211-1239.

[21] Escouflaire Ph., Dumont P., Maniere J., Leon D., Mercier A., Bouchard F., Tainturier D., Fieni F., Bruyas J.F., Recherche d'une dose optimale de P-FSH dans la superovulation des bovins, 5th Scientific Meeting A.E.T.E., Lyon, 8-9 September 1989, Proc. 150.

[22] Fernandes C.A.C., Viana J.H.M., Ferreira A.M., Vieira M.R., Follicular population and superovulatory response in cows and heifers, Theriogenology 57 (2002) 606.

[23] Gong J.G., Armstrong D.G., Baxter G., Hogg C.O., Garnsworthy P.C., Webb R., The effect of increased dietary intake on superovulatory response to FSH in heifers, Theriogenology 57 (2002) 1591-1602.

[24] Gonzalez A., Lassier J.G., Carruthers T.D., Murphy B.D., Mapletoft R.J., Superovulation of beef heifers with Folltropin: A new FSH Preparation containing reduced LH activity, Theriogenology 33 (1990) 519-529.

[25] Gonzalez A., Wang H., Carruthers T.D., Murphy B.D., Mapletoft R.J., Superovulation in the cow with pregnant mare serum gonadotrophin: effects of dose and antipregnant mare serum gonadotrophin serum, Can. Vet. J. 35 (1994) $158-162$.

[26] Gosselin N., Price C.A., Roy R., Carriere P.D., Decreased LH pulsatility during initiation of gonadotropin superovulation treatment in the cow: evidence for negative feedback other than estradiol and progesterone, Theriogenology 54 (2000) 507-521.

[27] Greve T., Callesen H., Hyttel P., Characterization of plasma LH profiles in superovulated dairy cows, Theriogenology 21 (1984) 237.

[28] Guilbault L.A., Grasso F., Lussier J.G., Rouillier P., Matton P., Decreased superovulatory responses in heifers superovulated in the presence of a dominant follicle, J. Reprod. Fertil. 91 (1991) 81-89.

[29] Herrler A., Elsaesser F., Parvizi N., Niemann H., Superovulation of dairy cows with purified FSH supplemented with defined amounts of $\mathrm{LH}$, Theriogenology 35 (1991) 633-643.

[30] Huhtinen M., Rainino V., Alato J., Bredbacka P., Maki-Tanila A., Increased ovarian response in the absence of a dominant follicle in the superovulated cow, Theriogenology 37 (1992) 457-463.

[31] Kafi M., McGowan M.R., Factors associated with variation in the superovulatory response of cattle, Anim. Reprod. Sci. 48 (1997) 137-157. 
[32] Kanitz W., Schneider F., Becker F., Zum Einfluß der FSH-Dosis auf Prozesse des Follikelwachstums und Superovulationsergebnisse beim Rind, Arch. Anim. Breed. 39 (1996) 387-400.

[33] Kanitz W., Pöhland R., Becker F., Viergutz T., Gonadotropin binding by granulosa cells after superovulatory treatment with different FSH/LH ratios in cattle, 14th Scientific Meeting A.E.T.E., Venice, 11-12 September 1998, Proc. 178

[34] Kanitz W., Brüssow K.-P., Becker F., Torner H., Schneider F., Kubelka M., Tomek W., Comparative aspects of follicular development, follicular and oocyte maturation and ovulation in cattle and pigs, Arch. Anim. Breed. 44 (2001) 9-23.

[35] Kawamata M., Relationships between the number of small follicles prior to superovulatory treatment and superovulatory response in Holstein cows, J. Vet. Med. Sci. 56 (1994) 965-967.

[36] Kelly P., Duffy P., Roche J.F., Boland M.P., Superovulation in cattle: effect of FSH type and method of administration on follicular growth, ovulatory response and endocrine patterns, Anim. Reprod. Sci. 46 (1997) 1-14.

[37] Kim I.H., Son D.S., Yeon S.H., Choi S.H., Park S.B., Ryu I.S., Suh G.H., Lee D.W., Lee C.S., Lee H.J., Yoon J.T., Effect of dominant follicle removal before superstimulation on follicular growth, ovulation and embryo production in Holstein cows, Theriogenology 55 (2001) 937-945.

[38] Kohram H., Bousquet D., Durocher J., Guilbault L.A., Alteration of follicular dynamics and superovulatory responses by gonadotropin releasing hormone and follicular puncture in cattle: a field trial, Theriogenology 49 (1998) 1165-1174.

[39] Kohram H., Twagriramung H., Bousquet D., Durocher J., Guilbault L.A., Ovarian supersstimulation after folicular wave synchronization with GnRH at two different stages of the estrous cycle in cattle, Theriogenology 49 (1998) 1175-1186.

[40] Kruip Th.A.M., Dieleman S.J., Macroscopic classification of bovine follicles and its validation by micromorphological and steroid biochemical procedures, Reprod. Nutr. Dev. 22 (1982) 465-473.

[41] Laurincik J., Oberfranc M., Hyttel P., Grafenau P., Tomanek M., Pivko J., Characterization of the periovulatory period in superovulated heifers, Theriogenology 39 (1993) 537-544.

[42] Lerner S.P., Thayne W.V., Baker R.D., Henschen T., Meredith S., Inskeep E.K., Dailey R.A., Lewis P.E., Butcher R.L., Age, dose of FSH and other factors affecting superovulation in Holstein cows, J. Anim. Sci. 63 (1986) 176-183.

[43] Lindsell C.E., Rajkumar K., Manning A.W., Emery S.K., Mapletoft R.J., Murphy B.D., Variability in FSH:LH ratios among batches of com- mercially available gonadotrophins, Theriogenology 25 (1986) 167

[44] Mapletoft R.J., Gonzales A., Lussier J.G., Superovulation of beef heifers with Folltropin or FSH-P, Theriogenology 29 (1988) 274.

[45] Martinuk S.D., Manning A.W., Black W.D. Murphy B.D., Effects of carbohydrates on the pharmacokinetics and biological activity of equine chorionic gonadotropin in vivo, Biol. Reprod. 45 (1991) 598-604.

[46] Mauleon P., Mariana J.C., Benoit M., Solari A. Chupin D., Action upon the ovulation number and yield of French Friesian cows of differen PMSG and HCG doses injected during the follicular phase of the oestrous cycle, Ann. Biol. Anim. Bioch. Biophys. 10 (1979) 31-46.

[47] McGowan M.R., Braithwaite M., Jöchle W., Mapletoft R.J., Superovulation of beef heifers with pergonal (HMG): A dose response trial, Theriogenology 24 (1985) 173-184.

[48] Murphy M.G., Boland M.P., Roche J.F., The effects of dose and duration of administration of pFSH during the first follicular wave on the ovulation rate of beef heifers, Theriogenology 49 (1998) 557-569.

[49] Pöhland R., Kanitz W., Schneider F., Blödow G., Wertbemessung gonadotroper Hormone, Mh. Vet.-Med. 46 (1991) 328-331.

[50] Purwantara B., Callesen H., Greve T., Characteristics of ovulations in superovulated cattle, Anim. Reprod. Sci. 37 (1994) 1-5.

[51] Purwantara B., Schmidt M., Callesen H., Greve T., Follicular development and embryo recovery following 3 versus 8 FSH injections in heifers, Acta Vet. Scand. 35 (1994) 89-92.

[52] Ramsbottom G., Baguisi A., Duffy P., Roche J.R., Boland M.P., Superovulation of heifers using FSH with high or low LH content, 9th Scientific Meeting A.E.T.E., Lyon, 10-11 September 1993, Proc. 264

[53] Roche J.F., Control and regulation of folliculogenesis - a symposium in perspective, Rev. Reprod. 1 (1996) 19-27.

[54] Romero A., Albert J., Brink Z., Seidel G.E. Jr., Number of small follicles in ovaries affect superovulatory response in holstein cows treated with FSH-P in different endocrine states, Theri ogenology 35 (1991) 915-929.

[55] Saumande J., Superovulation chez les bovins : actualités et perspectives, 3rd Scientific Meeting A.E.T.E., Lyon, 4-5 September 1987, Proc. 97-141.

[56] Saumande J., Chupin D., Induction of superovulation in cyclic heifers: The inhibitory effect of large doses of PMSG, Theriogenology 25 (1986) 233-247.

[57] Saumande J., Chupin D., Effect of LH activity of superovulatory hormones on inhibition of ovulation in cases of hyperstimulation, 6th Scientific Meeting A.E.T.E., Lyon, 7-8 September 1990 Proc. 184. 
[58] Schallenberger E., Ulrich P., Mostl E., Fuchs S., Tenhumberg H., Induction of Superovulation in cattle comparing single subcutaneous and repeated epidural with standard intramuscular administration of FSH, Theriogenology 41 (1994) 290.

[59] Shaw D.W., Good T.E., Recovery rates and embryo quality following dominant follicle ablation in superovulated cattle, Theriogenology 53 (2000) 1521-1528.

[60] Singh S.P., Broadbent P.J., Hutchinson J.S.M., Watt R.G., Dolman D.F., Follicular dynamics and superovulatory response in heifers, Anim. Reprod. Sci. 43 (1996) 183-190.

[61] Staigmiller R.B., MacNeil M.D., Bellows R.A., Short R.E., Superovulation of beef heifers with single vs. multiple injections of Folltropin, Proc. 12th Int. Congr. Anim. Reprod., The Hague, 1 , 272-274.

[62] Stanton P.G., Pozvek G., Burgon P.G., Robertson D.M., Hearn M.T.W., Isolation and characterization of human LH isoforms, Endocrinology 138 (1993) 529-543.

[63] Sugano M., Watanabe S., Use of highly purified porcine FSH preparation for superovulation in Japanese black cattle, J. Vet. Med. Sci. 59 (1997) 223-225.

[64] Sugano M., Shinogi T., Superovulation induction in Japanese Black cattle by a single intramuscular injection of hMG or FSH dissolved in polyvinylpyrrolidone, Anim. Reprod. Sci. 55 (1999) 175-181.

[65] Suzuki T., Yamamoto M., Oe M., Takagi M., Superovulation of beef cows and heifers with a single injection of FSH diluted in polyvinylpyrrolidone, Vet. Rec. 135 (1994) 41-42.

[66] Takagi M., Kim I.H., Izadyar F., Hyttel P., Bevers M.M., Dieleman S.J., Hendriksen P.J., Vos P.L., Impaired final follicular maturation in heifers after superovulation with recombinant human FSH, Reproduction 121 (2001) 941-951.

[67] Tribulo H., Bo G.A., Jofre F., Carcedo J., Alonso A., Mapletoft R.J., The effect of LH concentration in a porcine pituitary extract and season on superovulatory response in Bos indicus heifers, Theriogenology 35 (1991) 286.

[68] VanDijk S., Ward D.N., Heterogeneity in porcine pituitary luteinizing hormone: Amino acid and carbohydrate analysis, Endocrinology 130 (1992) 1966-1974.

[69] Walton J.S., Stubbings R.B., Factors affecting the yield of viable embryos by superovulate holstein-friesian cows, Theriogenology 26 (1986) 167-177.
[70] Wehrman M.E., Fike K.E., Kojiman F.N. Bergfeld E.G., Cupp A.S., Mariscal V., Sanchez T., Kinder J.E., Development of persistent ovarian follicles during synchronization of estrus influences the superovulatory response to FSH treatment in cattle, Theriogenology 45 (1996) 593-610.

[71] Willmott N., Sounders J., Bo G.A., Palasz A., Pierson R.A., Mapletoft R.J., The effect of FSH/LH ratio in pituitary extracts on superovulatory response in the cow, Theriogenology 33 (1990) 347.

[72] Wilson J.M., Moore K., Jones A.L., Looney C.R., Recombinant bovine follicle-stimulating hormone: Dose and duration regimes for superovulation of embryo donors, Theriogenology 31 (1989) 273.

[73] Wilson J.M., Jones A.L., Moore K., Looney C.R., Bondioli K.R., Superovulation of cattle with a recombinant-DNA bovine follicle stimulating hormone, Anim. Reprod. Sci. 33 (1993) $71-82$.

[74] Wiltbank M.C., Gümen A., Sartori R., Physiological classification of an ovulatory conditions in cattle, Theriogenology 57 (2002) 21-52.

[75] Wubishet A., Kesler D.J., Graves C.N., Spahr S.L., Favero R.J., Preovulatory LH profiles of superovulated cows and progesterone concentrations at embryo recovery, Theriogenology 35 (1991) 451-457.

[76] Yadav M.C., Walton J.S., Leslie K.E., Plasma concentrations of luteinizing hormone and progesterone during superovulation of dairy cows using follicle stimulating hormone or pregnant mare serum gonadotrophin, Theriogenology 26 (1986) 523-540.

[77] Yadav M.C., Walton J.S., Leslie K.E., Timing of the onset and duration ovulation of ovulation in superovulated beef heifers, Theriogenology 26 (1986) 509.

[78] Yamamoto M., Ooe M., Fujii C., Suzuki T., Superovulation in cows given a single intramuscular injection of follicle stimulating hormone dissolved in polyvinyl pyrolidone, J. Japan. Vet. Med. Assoc. 46 (1993) 554-556.

[79] Yamamoto M., Ooe M., Fujii C., Suzuki T. Superovulation of Japanese black heifers treated with FSH-P and FSH-R, J. Vet. Med. Sci. 55 (1993) 133-134.

[80] Zalesky D.D., Nett T.M., Grotjan H.E., Ovine luteinizing hormone: isoforms in the pituitary during the follicular and luteal phases of the estrous cycle and during anestrus, J. Anim. Sci. 70 (1992) 3851-3856. 